\title{
Effect of Glucosuria on the Perfomance of Small-scale Onsite Wastewater Treatment Plants-II. Biotreatment Characteristics
}

\author{
MASAHARU TADOKORO', TAKEHIKO OGAWA ${ }^{2}$, \\ TOSHIRO SAKURAI', and SHIGERU OHNO ${ }^{3}$ \\ ${ }^{1}$ Kanagawa Environmental Research Center/842, Nakaharashimojuku, Hiratsuka-shi, Kanagawa 254, Japan \\ ${ }^{2}$ Kanagawa Prefectural Public Health Laboratories/52-2 Nakaocho Asahi-ku Yokohama 241, Japan \\ ${ }^{3}$ Kitasato University/1-15-1, Kitasato, Sagamihara-shi, Kanagawa 228, Japan
}

\begin{abstract}
Experimental investigations using the model reactors of both separation and aeration in the small-scale onsite wastewater treatment plant (SOWTP) was carried out in order to evaluate its malfunction for domestic use caused by glucosuria. When wastewater containing glucosuria was anaerobically digested, acid fermentation occurred, causing accumulation of volatile fatty acids (VFAs) at high concentrations. When the BOD loading was high, the VFAs generated were primarily malodorous propionic acid, butyric acid, and valeric acid. Therefore, the decreases in $\mathrm{pH}$ and the occurrence of a bad odor in the sedimentation-separation chamber (the primary treatment chamber) of SOWTPs are considered to be due to acid fermentation of glucosuria. Furthermore, when the anaerobic digestion effluent (the primary effluent) was treated with activated sludge at a BOD-SS loading of $0.31 \mathrm{~kg} / \mathrm{kg} \cdot$ day or less, the BOD removal efficiency was $93 \%$ or higher if DO was maintained at a high level. Therefore, the lack of air supply in the aeration chamber (the secondary treatment chamber) is considered to be a major cause of deterioration of the final effluent, and that quality of the final effluent is considered to be improved by a marked increase in the air supply.
\end{abstract}

Key words : glucosuria, small-scale onsite wastewater treatment plant, anaerobic digestion, VFA, activated sludge treatment.

\section{INTRODUCTION}

In the small-scale onsite wastewater treatment plants (SOWTPs) for domestic use, the final effluent is often deteriorated and the offensive odor is generated due to their mal- function. Especially in case of treating the wastewater from houses inhabited by patients with diabetes, the serious problems on its treatment has been reported as follows ${ }^{1)}$ :

(1) The pHs in the sedimentation-separation 
and the aeration chambers decreased nearly to 4 with the offensive odor.

(2) Low dissolved oxygen (DO) is regarded in the aeration chamber and the settleability of activated sludge is remarkably deteriorated.

(3) The concentrations of volatile fatty acids (VFAs), BOD and SS in the final effluent become higher, such as VFAs concentration of several hundred $\mathrm{mg} / l$.

According to the questionnaire survey on the effect of influent matters in SOWTPs ${ }^{2}$, it was reported that the $1.03 \%$ of the total plants had experienced some troubles due to glucosuria. In our previous report ${ }^{3)}$, it was shown that BOD concentration in the final effluent of SOWTPs increased by urine from the severely diabetic patients and that this increase in the BOD loading due to glucosuria was a main cause of the malfunction of SOWTPs.

In this paper, on the basis of these results, experimental investigations using the model reactors of both separation and aeration for the flush toilets were carried out in order to evaluate the malfunction of SOWTP caused by glucosuria.

\section{MATERIALS AND METHODS}

Substrates and seed sludges Urine of a patient with severe diabetes mellitus (saccharides concentration: about $40,000 \mathrm{mg} / \mathrm{l}$, BOD concentration: about $30,000 \mathrm{mg} / l$ ) was diluted 50 and 25 times and used as experimental glucosuric wastewater. Table 1 shows the properties of the glucosuric wastewater. Anaerobic digestion sludge and activated sludge of a night soil treatment plant were used as seed sludges for the start-up of the reactors. Both sludges were acclimatized for 2 months.

Experimental apparatuses and conditions The model reactors of both separation and aeration in the separation-aeration type SOWTPs for the flush toilet were used in this study. Figure 1 shows the schematic views of the two circular reactors.

Table 1 Characteristics of glucosuric wastewater using the anaerobic digestion treatment

\begin{tabular}{lccc}
\hline \multicolumn{2}{c}{ Glucosuric wastewater } & $\mathrm{A}$ & $\mathrm{B}$ \\
\hline $\mathrm{pH}$ & & 6.5 & 6.5 \\
$\mathrm{~B}$ O D & $(\mathrm{mg} / l)$ & 610 & 1,220 \\
$\mathrm{C}$ O D & $(\mathrm{mg} / l)$ & 540 & 1,080 \\
$\mathrm{~T}$ O C & $(\mathrm{mg} / l)$ & 378 & 756 \\
$\mathrm{~S} \mathrm{a} \mathrm{c}$ & $(\mathrm{mg} / l)$ & 760 & 1,520 \\
$\mathrm{~S} \mathrm{~S}$ & $(\mathrm{mg} / l)$ & 1 & 2 \\
$\mathrm{~N} \mathrm{H}_{4}-\mathrm{N}$ & $(\mathrm{mg} / l)$ & 9.1 & 18.2 \\
$\mathrm{~N} \mathrm{O}_{2}-\mathrm{N}$ & $(\mathrm{mg} / l)$ & $\mathrm{ND}$ & $\mathrm{ND}$ \\
$\mathrm{N} \mathrm{O}_{3}-\mathrm{N}$ & $(\mathrm{mg} / l)$ & $\mathrm{ND}$ & $\mathrm{ND}$ \\
$\mathrm{T}-\mathrm{N}$ & $(\mathrm{mg} / l)$ & 69.5 & 139 \\
$\mathrm{P} \mathrm{O}_{4}-\mathrm{P}$ & $(\mathrm{mg} / l)$ & 2.03 & 4.07 \\
$\mathrm{~T}-\mathrm{P}$ & $(\mathrm{mg} / l)$ & 5.80 & 11.6 \\
$\mathrm{C}{ }^{-}$ & $(\mathrm{mg} / l)$ & 64 & 129 \\
\hline
\end{tabular}

A and B: Urine of a patient with severe diabetes mellitus diluted 50 and 25 times, respectively. Sac: Saccharides, ND: not detected. 
(2)

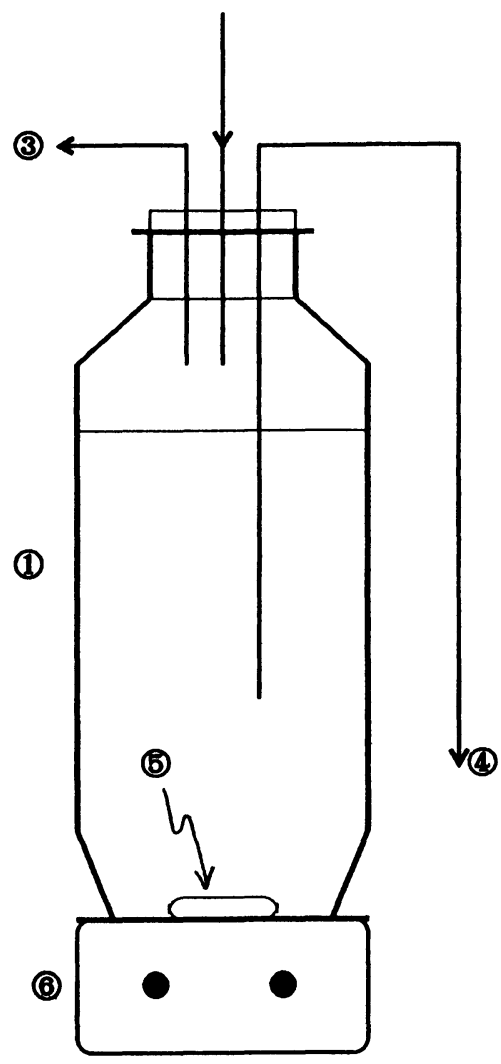

(a) Anaerobic digestion apparatus

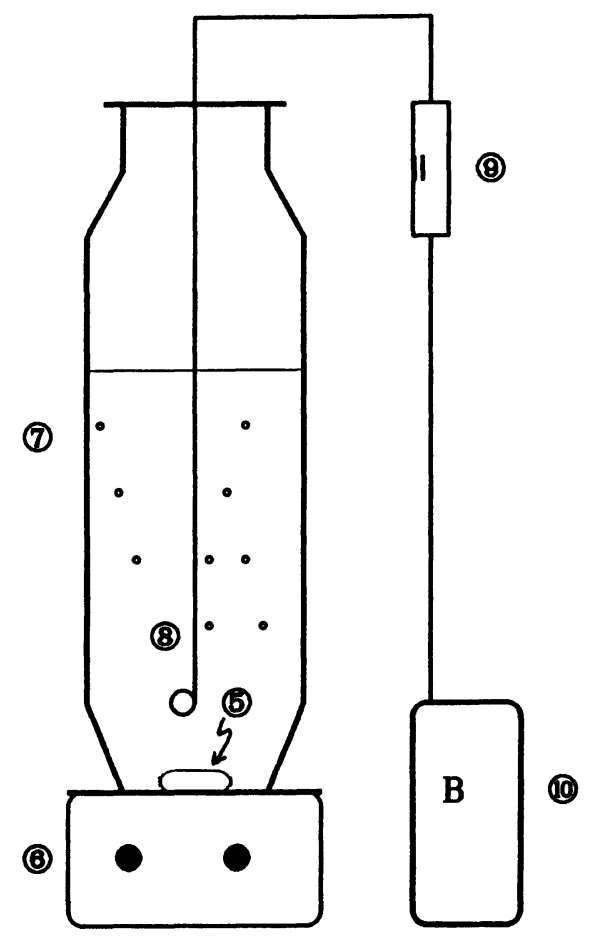

(b) Activated sludge apparatus

Fig. 1 Experimental apparatuses. Legends: (1),Anaerobic digestion reactor; (2),Feed charging pipe; (3),Gas dischrge pipe; (4),Draining pipe; (5), Stirrer bar; (6),Magnetic mixer; (7),Activated sludge reactor; (8), Diffuser; (9), Air flow meter; (10),Blower.

Fig. 1 (a) shows the anaerobic digestion reactor(3.6 l), and it was operated as the sedimentation-separation chamber (the primary treatment) of SOWTP. The contents of the reactor was stirred once a day, a fixed amount of the mixed contents was drawn and centrifuged (1,500 rpm, $5 \mathrm{~min}$.), and the supernatant was regard as anaerobic digestion effluent (primary effluent). The influent (glucosuric wastewater) was added after collection of the effluent.
Fig. 1 (b) shows the activated sludge reactor $(1 l)$, and it was operated as the aeration chamber (the secondary treatment) of SOWTP. The contents were aerated by bubbling or stirring. A fixed amount of the mixed contents was collected once a day, allowed to stand for 30 minutes, and the supernatant was regarded as activated sludge effluent (secondary effluent). The influent (anaerobic digestion effluent) was added after collection of the effluent. 
Table 2 shows experimental conditions, which were established on the basis of design values for 5 persons. The experimental period was a month after acclimation. All experiments were performed in a climatic room adjusted to $20{ }^{\circ} \mathrm{C}$.

Analytical methods Water quality analysis was performed according to the standard methods for the examination of wastewater $(1984 \text { version })^{4}$. Saccharides were determined by the Anthron method ${ }^{5)}$, and VFAs by HPLC.

\section{RESULTS AND DISCUSSION}

\section{Anaerobic digestion}

Removal of organic matter The separation-aeration process of the SOWTP combines the use of a sedimentation-separation chamber and an aeration chamber. The sedimentation-separation chamber is struc- turally identical with a septic tank, and its functions are sedimentation-separation and anaerobic digestion of the wastewater. The anaerobic treatment of the glucosuric wastewater simulating digestion in the sedimentation-separation chamber obtained the results shown in Table 3 .

The $\mathrm{pH}$ of the anaerobic digestion effluent decreased to 4.2-5.5. Saccharides were satisfactorily separated, and more than $90 \%$ of them were eliminated in both Run-1 (BOD loading: $\left.0.2 \mathrm{~kg} / \mathrm{m}^{3} \cdot \mathrm{day}\right)$ and Run-2 (0.4 $\mathrm{kg} / \mathrm{m}^{3} \cdot$ day). Matsushita et $a l .{ }^{6)}$ studied differences in acid fermentation characteristics according to the substrate composition in the wastewater, and reported that $\mathrm{pH}$ decreased markedly when the wastewater contained primarily glucose but increased when its protein content was increased. Since saccharides, especially glucose, are observed in glucosuria, the marked decrease in $\mathrm{pH}$ is

Table 2 Experimental conditions

(a) Anaerobic digestion treatment

\begin{tabular}{llcc}
\hline Run No. & & Run- & Run-2 \\
\hline Influent & & $\mathrm{A}$ & $\mathrm{B}$ \\
Influent BOD & $(\mathrm{mg} / l)$ & 610 & 1,220 \\
Flow rate & $(l /$ day $)$ & 1.2 & 1.2 \\
HRT & $($ day $)$ & 3.0 & 3.0 \\
BOD loading & $\left(\mathrm{kg} / \mathrm{m}^{3} \cdot\right.$ day $)$ & 0.20 & 0.41 \\
\hline \multicolumn{4}{c}{ Effective volume of tank: $3.6 \mathrm{~L}$, Temp: $20^{\circ} \mathrm{C}}$.
\end{tabular}

(b) Activated sludge treatment

\begin{tabular}{llcccc}
\hline Run No. & & Run- 3 & Run- 4 & Run- 5 & Run- 6 \\
\hline Influent & & $\begin{array}{c}\text { Effluent } \\
\text { from Run-1 }\end{array}$ & $\begin{array}{c}\text { Effluent } \\
\text { from Run-2 }\end{array}$ & $\begin{array}{c}\text { Effluent } \\
\text { from Run-1 }\end{array}$ & $\begin{array}{c}\text { Effluent } \\
\text { from Run-2 }\end{array}$ \\
Influent BOD & $(\mathrm{mg} / l)$ & $410-600$ & $940-1,120$ & $410-600$ & $940-1,120$ \\
Flow rate & $(l /$ day) & 0.6 & 0.6 & 0.6 & 0.6 \\
HRT & $(\mathrm{h})$ & 40 & 40 & 40 & 40 \\
BOD-SS loading & $(\mathrm{kg} / \mathrm{kg} \cdot$ day) & $0.14-0.21$ & $0.25-0.36$ & $0.09-0.17$ & $0.21-0.31$ \\
DO & $(\mathrm{mg} / l)$ & $0.2-0.8$ & $0.2-0.8$ & $7.2-7.6$ & $6.8-7.6$ \\
\hline
\end{tabular}

Effective volume of tank: $1.0 l$, MLSS: $2,500 \pm 1,000 \mathrm{mg} / l$, Temp: $20^{\circ} \mathrm{C}$ 
considered to be due to acid fermentation of saccharides.

The removal efficiency of BOD was low; the mean removal efficiency was $22.8 \%$ in Run-1 and $14.9 \%$ in Run-2. The mean removal efficiency of TOC was also low at about $20 \%$. When the concentration of organic matter does not decrease by anaerobic digestion, organic matter in wastewater may be converted only to VFAs by acid fermentation $^{7}$. $\mathrm{COD}_{\mathrm{Mn}}$ was eliminated by more than $80 \%$, because the oxidation efficiency of VFAs by $\mathrm{KMnO}_{4}$ was very low, being less than $10 \%$. This finding is consistent with accumulation of $\mathrm{VFAs}^{8}$.

Therefore, the cause of the reduction in $\mathrm{pH}$ in the tank contents and the rancidity in SOWTPs of diabetic households are considered to be acid fermentation of saccharides in the sedimentation-separation chamber.
Amounts and composition of VFAs generated

Table 4 shows the concentrations of VFAs generated in anaerobic digestion effluent. The mean total VFA concentrations were $353 \mathrm{mg} / l$ in Run-1 and $860 \mathrm{mg} / \mathrm{l}$ in Run-2, respectively, indicating greater accumulation of VFAs in Run-2. Since the VFA concentration was 2.4 times higher while the load was only 2 times greater in Run-2 than in Run-1, the rate of conversion to VFAs appears to increase with the load.

Figure 2 shows the composition of VFAs. Acetic acid is considered to be the primary VFA derived from glucose ${ }^{9}$. According to the study of Matsushita et $a l .^{6}$, also, acetic acid was generated in the greatest amount among total VFAs, and isomers of butyric acid and valeric acid were produced only in trace amounts. In this study, acetic acid accounted for $48 \%$ in Run-1, and no isomers were noted. However in Run-2, acetic acid

Table 3 Experimental results in anaerobic digestion treatment

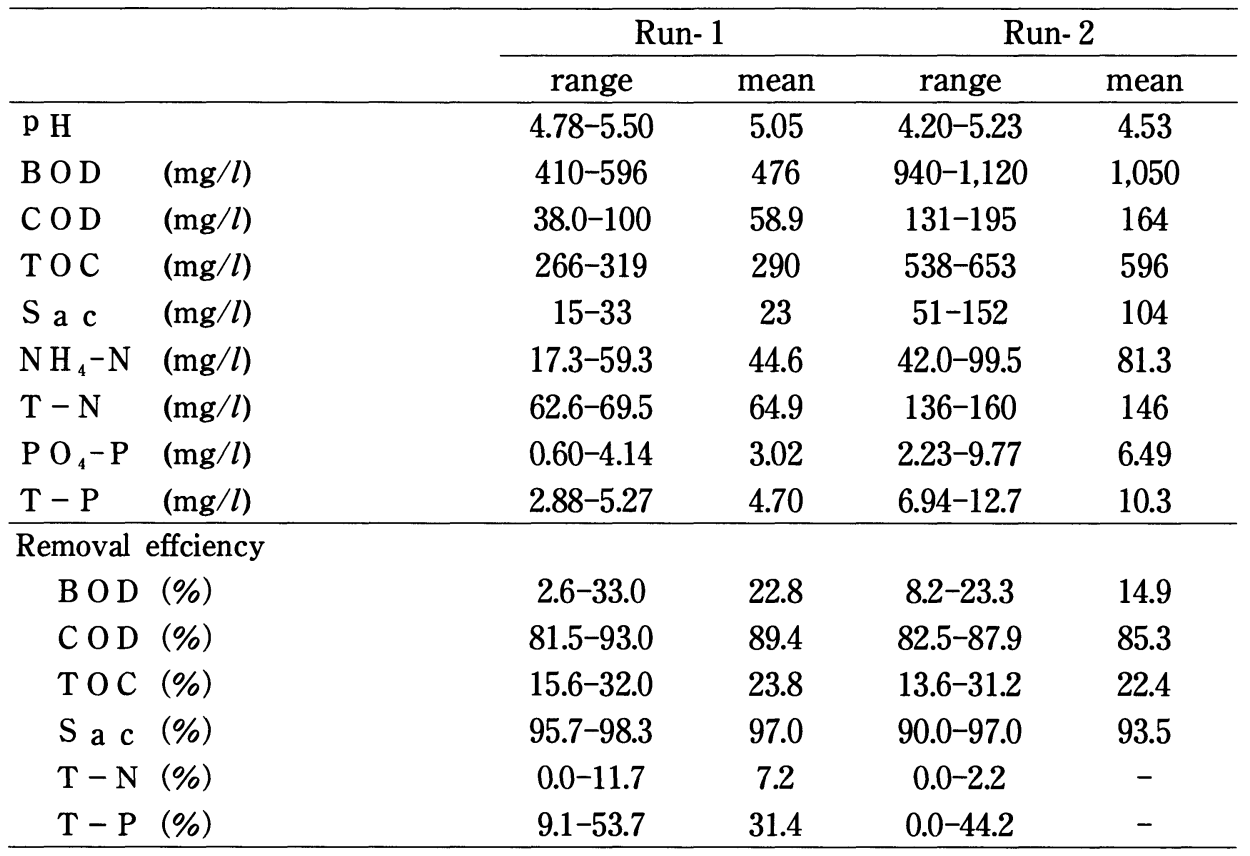

Sac: Saccharides. 


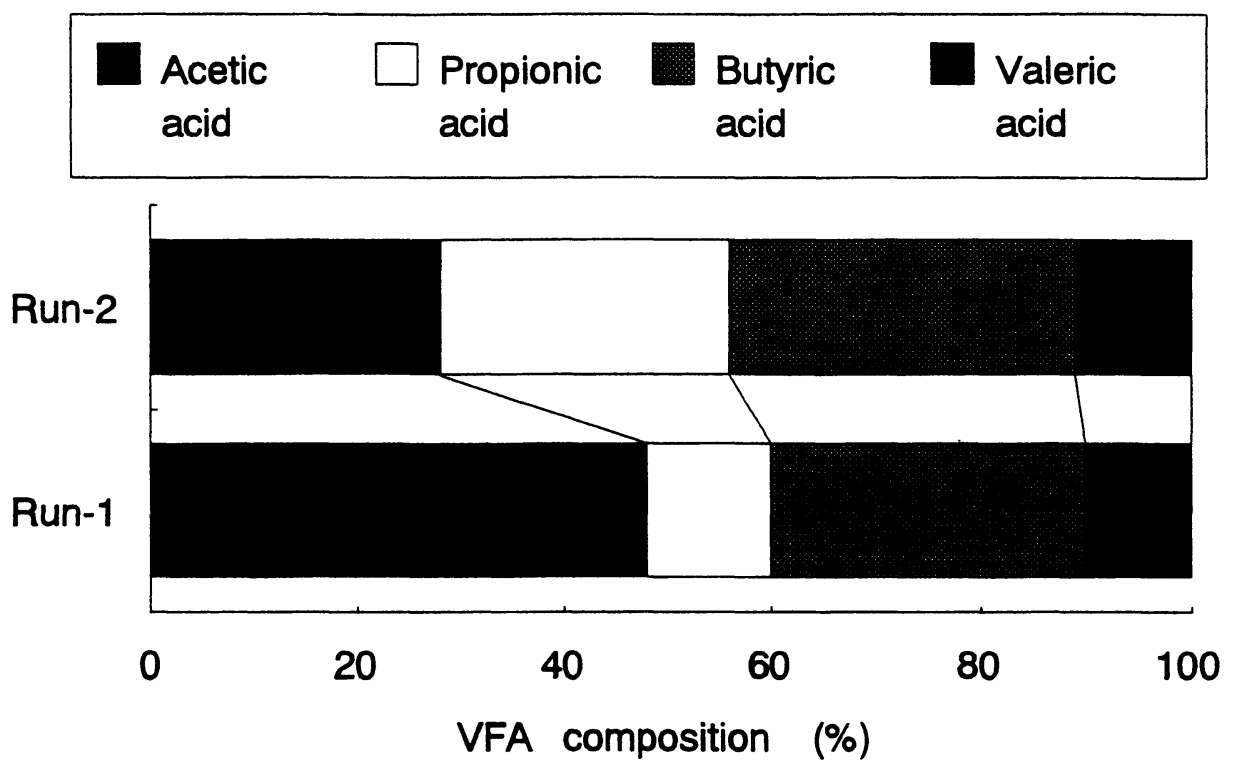

Fig.2 VFA composition of effluent in anaerobic digestion treatment

Table 4 VFA concentrations of influent and eflluent in anaerobic digestion treatment

\begin{tabular}{llcccc}
\hline & & \multicolumn{2}{c}{ Run- 1 } & \multicolumn{2}{c}{ Run-2 } \\
\cline { 2 - 6 } & & Influent & Effluent & Influent & Effluent \\
\hline Formic acid & $(\mathrm{mg} / l)$ & ND & ND & ND & ND \\
Acetic acid & $(\mathrm{mg} / l)$ & 13 & $156-181$ & 26 & $202-271$ \\
Propionic acid & $(\mathrm{mg} / l)$ & ND & $35-52$ & ND & $185-308$ \\
iso-Butyric acid & $(\mathrm{mg} / l)$ & ND & ND & ND & $6-14$ \\
$n$-Butyric acid & $(\mathrm{mg} / l)$ & ND & $100-116$ & ND & $248-296$ \\
iso-Valeric acid & $(\mathrm{mg} / l)$ & ND & ND & ND & $15-21$ \\
$n$-Valeric acid & $(\mathrm{mg} / l)$ & ND & $27-40$ & ND & $71-88$ \\
\hline Total & & 13 & $331-376$ & 26 & $755-922$ \\
& & & $(353)$ & & $(860)$ \\
\hline
\end{tabular}

Data based on 5 samples. Number in parentheses is the mean.

decreased to $28 \%$, and propionic acid increased to $28 \%$. As a result, the percentage of butyric acid became the greatest. Also $3.5 \%$ of butyric acid and $19 \%$ of valeric acid were isomers. The observations are supported by the following studies.
Braun $^{10)}$ reported that the propionic acid production surpassed the acetic acid production, and propionic acid became the primary component of VFAs, when the load of organic matter exceeded an appropriate range. According to Sakai et al. ${ }^{11)}$, also, anaerobic 


\section{- Low DO level (Run-3,4) $\square$ High DO level (Run-5,6)}

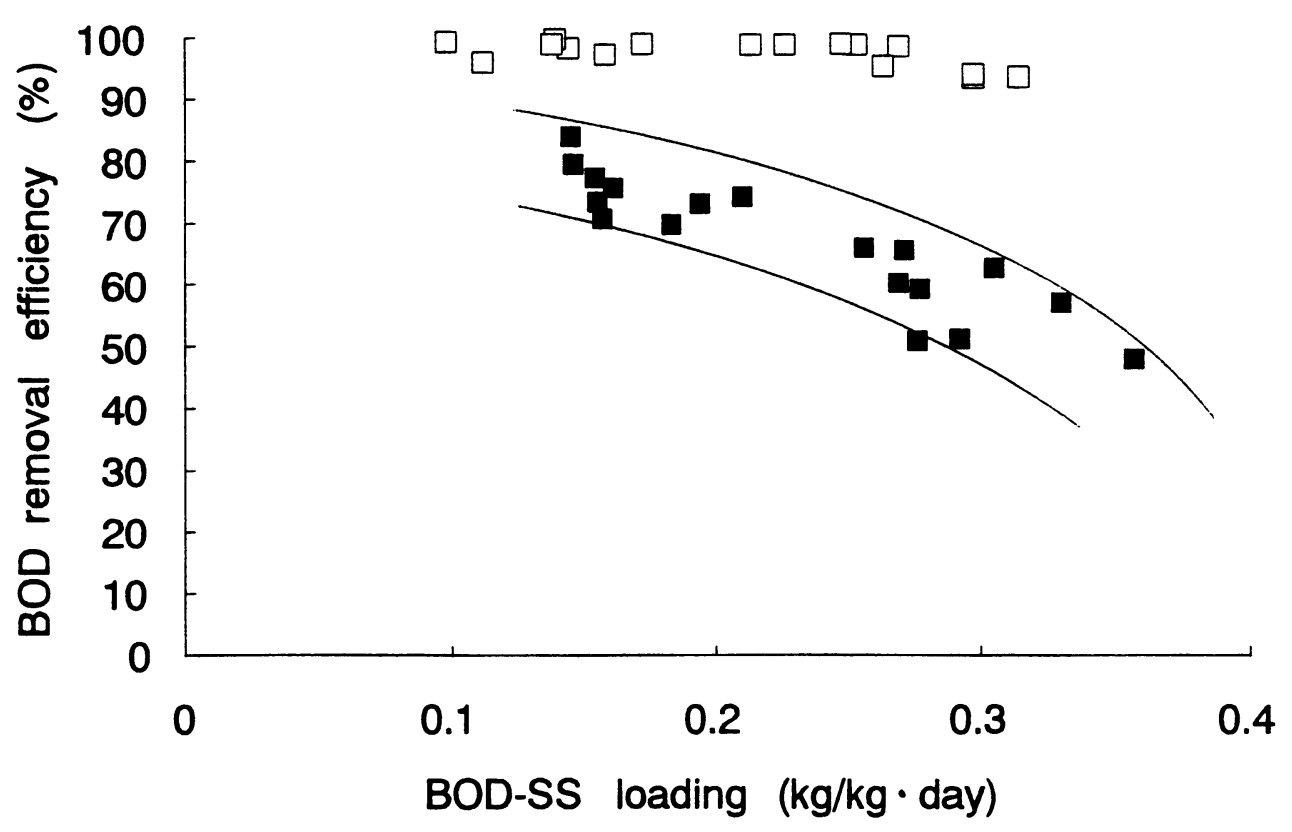

Fig.3 Relationship between BOD loading and BOD removal efficiency

treatment of experimental wastewaters primarily containing glucose (glucose concentration: $67-1,000 \mathrm{mg} / l$ ) resulted in production of VFAs, primarily acetic acid, the VFA production was greater as the glucose concentration was higher, and the percentages of propionic acid and butyric acid increased with the glucose concentration. Concerning the reason for these results, they speculated that propionic acid and butyric acid with relatively large molecular weights become less degradable to acetic acid at high glucose concentrations.

The twelve malodorous materials indicated by the Offensive Odor Control Law include 4 VFAs, namely, propionic acid, $n$-butyric acid, n-valeric acid, and iso-valeric acid. These materials are the primary causes of smell pollutions at livestock factories and starch manufacturing plants. In this study, the mean percentage of these 4 VFAs combined in total VFAs was $52 \%$ in Run- 1 and $71 \%$ in Run-2; it increased with the load. This suggests that dispersion of these VFAs by vaporization is the primary cause of the bad odor generated from SOWTPs of diabetic households. Aeration also may cause escape of a considerable amount of VFAs from wastewater to air ${ }^{12)}$.

\section{Activated sludge treatment}

Relationship between BOD removal and DO Since little DO was detected in SOWTPs that malfunctioned due to glucosuria, the deterioration of the quality of the final effluent appears to be caused primarily by the 


\section{- Low DO level (Run-3,4) $\square$ High DO level (Run-5,6)}

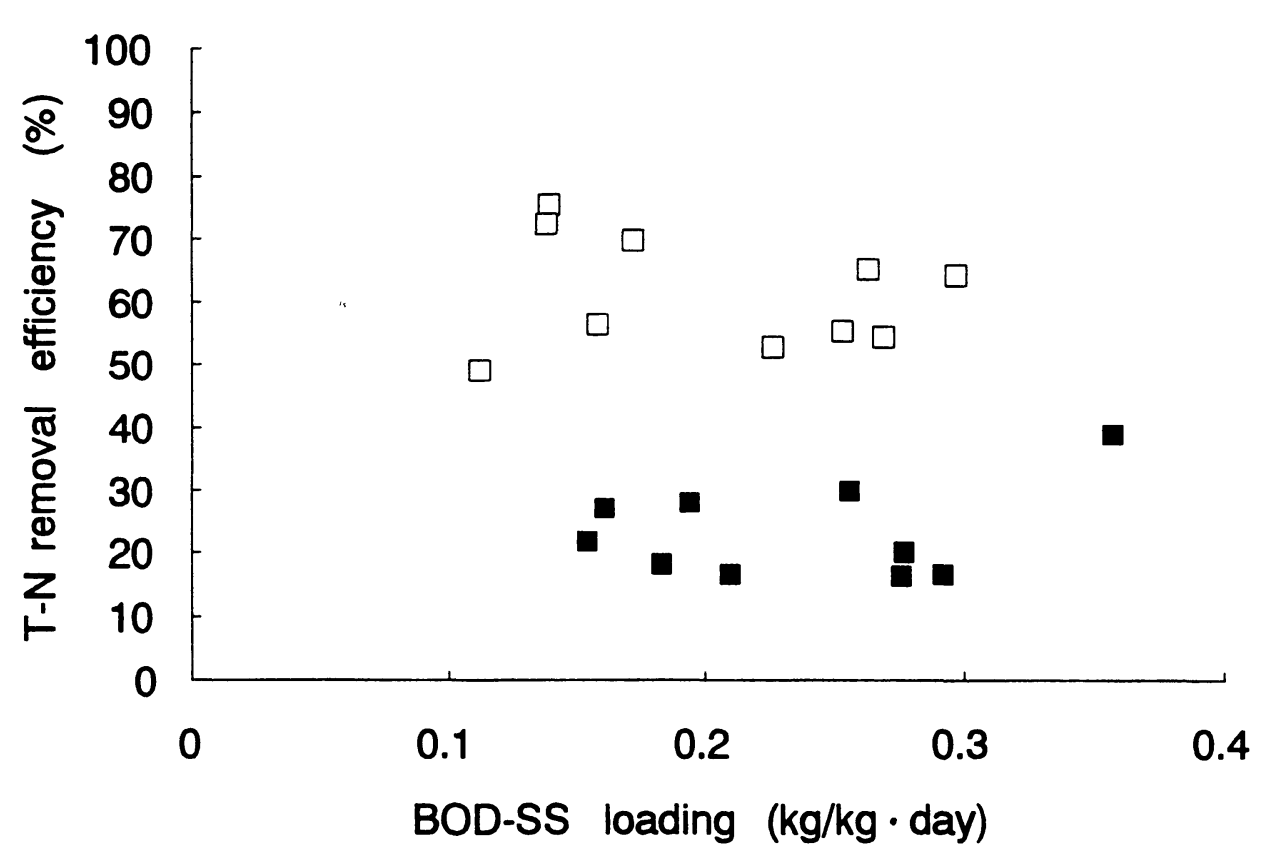

Fig.4 Relationship between BOD loading and T-N removal efficiency

lack of air supply to the aeration chamber. Therefore, when the anaerobic digestion effluent was treated with activated sludge by maintaining DO at a low level (about 0.2-0.8 $\mathrm{mg} / l$ ) for simulation of SOWTP malfunction due to glucosuria, the relationship between the BOD-SS loading and BOD removal efficiency was as shown in Fig. 3. The BOD removal efficiency was in the range of $70-84 \%$ when the BOD-SS loading was about $0.15 \mathrm{~kg} / \mathrm{kg} \cdot \mathrm{day}$, and it decreased to $48-62 \%$ when the BOD-SS loading was 0.3-0.35 $\mathrm{kg} / \mathrm{kg} \cdot$ day.

As we reported previously ${ }^{3)}$, the BOD-SS loading is estimated to be $0.14-0.23 \mathrm{~kg}$ $/ \mathrm{kg} \cdot$ day when MLSS is assumed to be 2,000 $\mathrm{mg} / l$ by simulating a separation-aeration type SOWTP (designed for 5 persons, the volume of the aeration chamber: $450 l$ ) that treats wastewater from a flush toilet of a family of 5 members including one patient with severe diabetes (BOD concentration: 492-816 mg/l, BOD load: 123-204 g/day). If air is supplied at a rate that permits detection of DO, BOD removal efficiency of $60 \%$ or higher is considered to be obtained at such a BOD loading range from Fig. 3 .

When the anaerobic digestion effluent was treated at a high DO level (DO about 7 $\mathrm{mg} / l$, air supply $15 \mathrm{l} / \mathrm{l} \cdot \mathrm{h}$ ), the BOD removal efficiency was $96 \%$ or less at a BOD-SS loading of $0.17 \mathrm{~kg} / \mathrm{kg} \cdot$ day or less and $93 \%$ or higher at a BOD-SS loading of 0.21-0.31 $\mathrm{kg} / \mathrm{kg} \cdot$ day. Therefore, if the air supply can be increased markedly, the performance standards (BOD in final effluent: $90 \mathrm{mg} / l$ or 


\section{- Low DO level (Run-3,4) $\square$ High DO level (Run-5,6)}

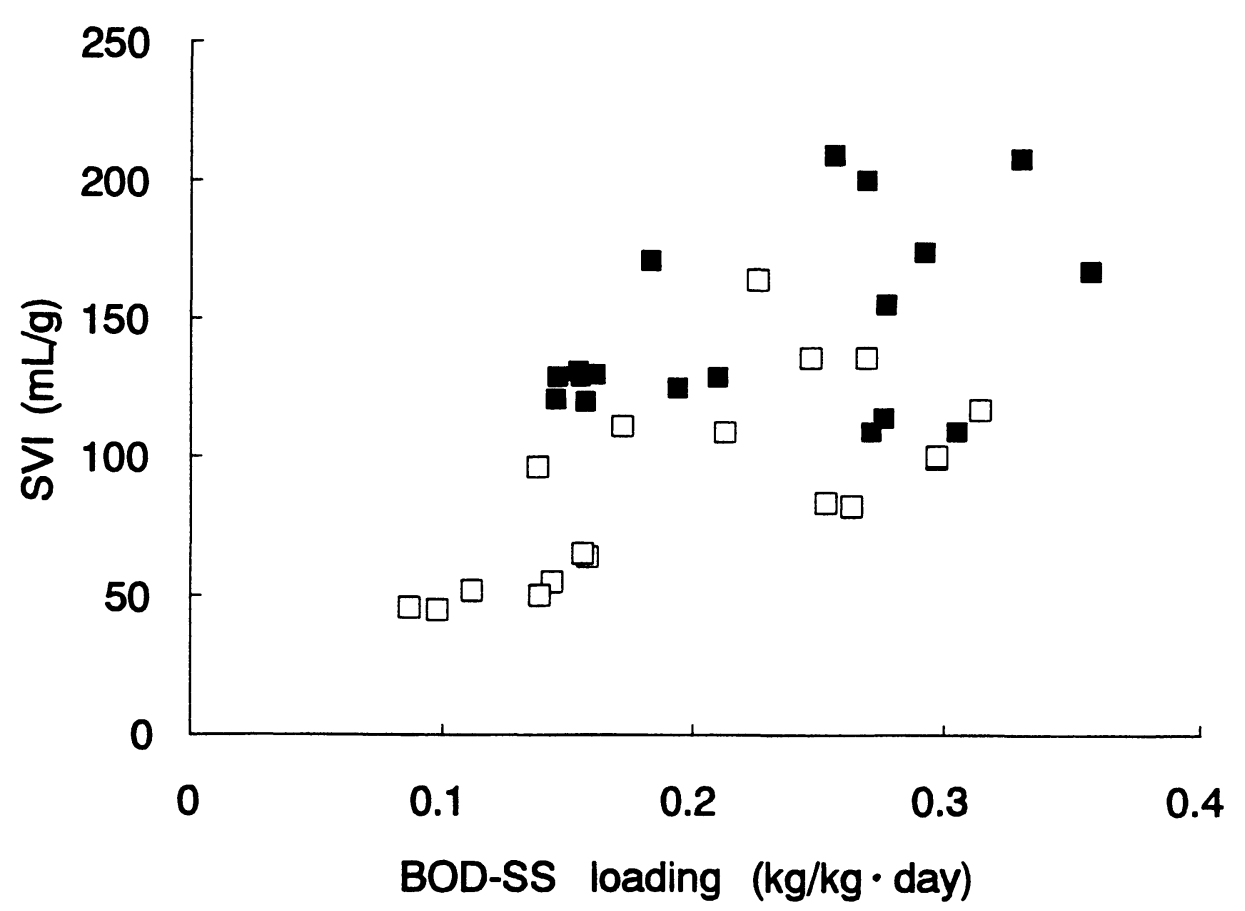

Fig.5 Relationship between BOD loading and SVI

less) can be satisfied even in SOWTPs of diabetic households. However, there is the possibility of deterioration of the quality of the final effluent due to the outflow of the sludge, because the amount of sludge generated increases in proportion to the amount of BOD removal.

Removal of nitrogen and phosphorus When the anaerobic digestion effluent was treated by maintaining $\mathrm{DO}$ at a low level, $\mathrm{T}-\mathrm{N}$ and $\mathrm{T}-\mathrm{P}$ removal efficiencies were $16-39 \%$ and 0-22\%, respectively (Fig.4).

On the other hand, when DO was maintained at a high level, high percentages of $\mathrm{T}-\mathrm{N}$ and $\mathrm{T}-\mathrm{P}$ as well as BOD were removed with removal efficiencies of $49-75 \%$ and $57-94 \%$, respectively. Since the ratios of BOD : $\mathrm{N}: \mathrm{P}$ were better balanced in the ex- perim ental wastewater $(100: 14: 1)$ than in normal urine or night soil, and since nitrogen was removed even when there was no progression of nitrification, $\mathrm{N}$ and $\mathrm{P}$ may have been consumed with BOD for sludge formation.

Biological nitrogen removal processes include the bacteria catabolic process, in which nitrogen is removed as it is taken up by bacteria in activated sludge, as well as the biological denitrification process. Helmers et $a l .{ }^{13) 14)}$ found that the nitrogen requirement of activated sludge is constant at 5-6 for every $100 \mathrm{BOD}$ removed. This provides the basis for the present standard of the necessary nitrogen balance of BOD : $N=100$ $: 5$. When this value is applied to Run-6, in which the anaerobic digestion effluent was 
treated (mean BOD removal efficiency: 96.7 $\%)$, the $\mathrm{N}$ is $51-61 \mathrm{mg} / l$ for the BOD of 1 , $015 \mathrm{mg} / l$. Therefore, the theoretical removal efficiency of $\mathrm{T}-\mathrm{N}$ is $58-65 \%$, which is close to the actual removal efficiency of $58 \%$. This suggests that more nitrogen is needed for sludge formation as the saccharides concentration is higher.

The high phosphorus removal efficiency is considered to be explained also by sludge formation.

Biota and settleability of activated sludge Chigusa $^{15)}$ reported that Sphaerotilus sp. became dominant in the aeration chamber of SOWTP used by diabetics and that the fungus Fusarium sp. was observed when activated sludge appeared pinkish. In this study, also, a large amount of fungi appeare $d$, the settleability of activated sludge was deteriorated, and SVI increased over 200 when anaerobic digestion effluent was treated in a low DO level (Fig.5). However, many activated sludge microorganisms such as Vorticella sp., Arcella sp., and Aspidisca sp. appeared in a high DO level. Then, the settleability of activated sludge was very good, and SVI was in the range of 50-150. Therefore, the lack of air supply is considered to be a cause of deterioration of the settleability of activated sludge.

Amount of slugde production In a high DO range (Run-5 and Run-6), the relationship between the amount of BOD removal from anaerobic digestion effluent and the increase in the amount of sludge was expressed by the following formula. The gross yield coefficient $a$ of sludge per removed BOD was 0.6 9.

$$
\Delta \mathrm{SS}=0.69 \mathrm{Lr}
$$

where,

$\Delta \mathrm{SS}=$ the amount of excess sludge production [kg/day],

$L r=$ the amount of removed BOD [kg/day].

Generally, the observed yield coefficient $a$ is reported to be $0.5-0.6$ for sewage and organic wastewater and to be $0.44-0.66$ for glucose $^{16)}$. Since it slightly exceeded these values in activated sludge treatment of anaerobic digestion effluent, the amount of sludge production is considered to be slightly greater than in common domestic wastewater.

Yagome $^{17)}$ reported that the amount of sludge production in the aeration chamber of the separation-aeration type SOWTP for the flush toilet wastewater was $2.2 \mathrm{~g}$ $\mathrm{SS} /$ person-day; that is, the amount of sludge production in the SOWTP designed for 5 persons is calculated to be $11 \mathrm{~g} \mathrm{SS} /$ day.

On the other hand, the amount of sludge production in a separation-aeration type SOWTP (designed for 5 persons) of a diabetic household is estimated to be 157 gSS/day by the previous formula when influent BOD, effluent BOD and flow rate in the aeration chamber are assumed to be $1,000 \mathrm{mg} / l, 90 \mathrm{mg} / l$ and $250 l /$ day, respectively.

$$
\begin{aligned}
& \Delta \mathrm{SS}=0.69 \times(1.0-0.09)[\mathrm{g} / l] \times 250[l / \text { day }] \\
& \quad=157[\mathrm{~g} / \text { day }]
\end{aligned}
$$

Namely, the amount of excess sludge production in a SOWTP of diabetic household is calculated to be 14.3 times as much as a one of normal household. Therefore, in SOWTP of diabetec households, even if the air is supplied enough in the aeration chamber, it is difficult to keep the good final effluent for SS generated by the sludge washout.

Measures to prevent SOWTP malfunction

The essential measure to prevent SOWTP malfunction is not to allow inflow of glucosuria into the SOWTP. For example, urine may be solidified with commercial urine solidifying agents and disposed of with garbage. Measures that can be taken in maintenance and cleaning of SOWTP are to extract sludge that has been produced in large amounts by frequent cleaning of the 
SOWTP and to increase the air supply. Temporary improvements in the function of SOWTP are expected by these measures. However, in our experience by field study, the activated sludge concentration in the aeration chamber increases again after 2 weeks resulting in rancidity. Another measure may be, as reported previously3), to change the SOWTP for flush toilet wastewater to a one for domestic wastewater to reduce the load by increasing the capacity.

\section{CONCLUSIONS}

An experimental investigations using the model reactors of both separation and aeration for the flush toilets were carried out in order to evaluate the malfunction of SOWTP caused by glucosuria. The results obtained are summarized as the following:

1) When glucosuric wastewater was digested anaerobically, the $\mathrm{pH}$ was reduced to $4.2-$ 5.5 by acid fermentation. Therefore, the decreases of $\mathrm{pH}$ in the sedimentationseparation chamber and the aeration chamber are considered to be due to acid fermentation of urinary saccharides.

2) Acetic acid was predominant in the organic acids produced by acid fermentation when the BOD load was low, but malodorous propionic acid, butyric acid, and valeric acid increased with the load. Therefore, these VFAs appear to be the primary cause of the bad odor.

3) When the anaerobic digestion effluent was treated with activated sludge at a BOD load of $0.31 \mathrm{~kg} / \mathrm{kg} \cdot$ day or less, the BOD removal efficiency was $93 \%$ or higher if DO was maintained at a high level. Therefore, the function of the aeration chamber is considered to be improved by a drastic increase in the air supply. However, the amount of sludge production is expected to markedly increase if the air supply is increased.

\section{References}

1) Ohno.S. : Handbook for Johkasou, The Industrial Water institute, 70-71, Tokyo (1981). (in Japanese)

2 ) Hisakawa.K., Niki.K. and Ohmori.H.: Inquiry on the effect of influent matters in johkasou, Proceedings of 23th Annual Conference of JSWE, 157-158 (1989). (in Japanese)

3 ) Tadokoro.M., Ogawa.T., Sakurai.T., and Ohno.S.: Effect of glucosuria on the performance of small-scale onsite wastewater treatment plants-I. water quality and malfunctioning, Japanese J. Wat.Treat.Biol., 31, 51-58 (1995)

4 ) Japan Sewage Works Assoc.:Standard methods for the examination of wastewater (1984). (in Japanese)

5 ) The Pharm. Soc. Jap.: Standard methods of analysis for hygienic chemists, Kanehara Publishing Co., Tokyo, 671-672 (1973). (in Japanese)

6 ) Matsusita.M.,Sato.K.,Okada.M.,Murakami. : Characteristics of acid fermentation in organic wastewater, Proceedings of 22th Annual Conference of JSWE, 259-260 (1988). (in Japanese)

7 ) EPA.: Design manual for onsite wastewater treatment and disposal systems, Office of water program operations and office of research and development, USA. EPA (1980)

$8)$ The Pharm. Soc. Jap.: Standard methods of analysis for hygienic chemists, Kanehara Publishing Co., Tokyo, 827-828 (1980). (in Japanese)

9 ) Nakamura, M., and Matsumoto,J. : Effect of retention time on the decomposition of glucose in an anaerobic filter process, Proceedings of the 43th Annual Conference of JSCE, 30-31 (1988). (in Japanese)

10) Braun,R.: Anaerobic filter treatment of 
molasses distillery slops, Water Research, 16, 1167-1171 (1982)

11) Sakai,A., Nakamura,M. and Matsumoto,J.: The fundamental study on the anaerobic metabolism of glucose, Proceedings of the 25th Annual Conference of Environmental and Sanitary Engineering Research of JSCE, 94-96 (1988). (in Japanese)

12) Namkung,E. and Rittmann,B.E.: Estimating volatile organic compound Emissions from publicly owned treatment works, J.WPCF, 59, 670 (1987)

13) Helmers,E.N., Anderson,E.J., Kilgore,H.D. Jr., Weinberger, L.W. and Sawyer,C.N.: Nutritional requirements in the biological stabilization of industrial wastes I. Experimental method, Sewage Ind. Wastes, 22, 1200-1206(1950)

14) Helmers,E.N., Frame,J.D., Greenberg,A.E. and Sawyer,C.N. : Nutritional requirements in the biological stabilization of industrial wastes II. Treatment with domestic sewage, Sewage Ind. Wastes, 23, 884-899 (1951)

15) Chigusa.K.: Controlling by activated sludge biota, Nishihara Environmental Sanitation Research Co., 77 (1979). (in Japanese)

16) Eckenfelder,W.W.Jr. and O'Connor,D.J.: Biological Waste Treatment, Pergamon press, New York, 54-55 (1961)

17) Yagome,K.: Design and Performance of individual Sewage Disposal Tank, J. Water and Waste, 23, 9-14 (1981). (in Japanese)

(Submitted 1995. 4.18)

(Accepted 1995. 5.18) 